\title{
Design Thinking
}

\section{Sidsel Bech-Petersen*}

\section{Design Thinking as a Framework for Innovation in Libraries}

https://doi.org/10.1515/bfp-2020-0009

\begin{abstract}
This article presents human-centered design methods as a way to create relevant and vibrant libraries. Dokk1-the main library in Aarhus-is co-created with users, partners, and stakeholders. It has become an open, flexible library space that also uses technology as a way to invite the users to become part of the space. Using design thinking as a new way of working, co-creation also becomes a part of developing new services and spaces and a new way of working for the library staff.
\end{abstract}

Keywords: Design thinking; innovation; co-creation; prototyping; user involvement

\section{Design Thinking als Gerüst für Neuerungen in Bibliothe- ken}

Zusammenfassung: Dieser Artikel stellt Entwicklungsmethoden dar, um sachbezogene und lebendige Bibliotheken, die den Mensch in den Mittelpunkt ihrer Arbeit stellen, ins Leben zu rufen. Dokk1, die Hauptbibliothek in Aarhus, wurde gemeinsam von Nutzern, Partnern und Interessenvertretern konzipiert. So wurde ein offener, flexibler Ort geschaffen, der modernste Technologien dazu verwendet, dass sich die Nutzer als Teil dieses Ortes verstehen. Durch die Einführung des Design Thinkings wurden neue Wege in der Zusammenarbeit, den Dienstleistungen und den Räumlichkeiten für die Mitarbeiter der Bibliothek geschaffen.

Schlüsselwörter: Design Thinking; Innovation; Co-Creation; Prototyp; Userbeteiligung

Dokk $1^{1}$ is a library for people-not for books. It represents the shift in library development from being media-oriented

1 In average we have 3,800 users per day at Dokk1-and every day the library space is co-created with partners and users. The users have embraced Dokk1, it is their space. About $60 \%$ of our events are

*Kontaktperson: Sidsel Bech-Petersen, sibp@aarhus.dk to being citizen-oriented. A citizen-oriented library requires co-creation on different levels-for example it requires a new way of working and that you see the library as an ongoing prototype.

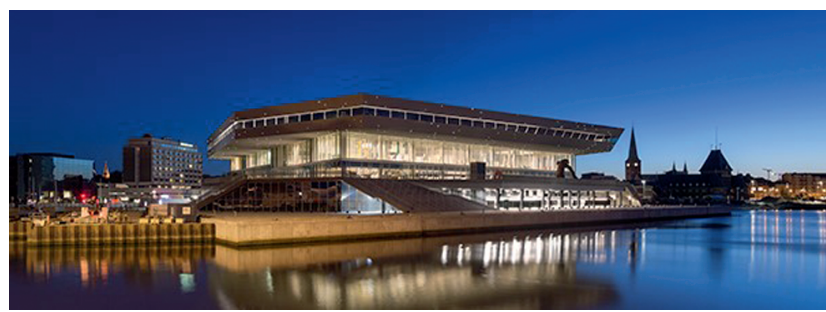

Fig. 1: Dokk1: the main library in Aarhus, Denmark. Photo: Aarhus Public Libraries

\section{Dokk1: Design thinking as DNA}

When Dokk1 opened its doors to the public on June 20 2015, it became Scandinavia's largest public library, representing a new generation of modern, hybrid libraries. The leading idea about the building is that the library space is a covered urban space; and it is a space is for people, not just for books. Thatswhy, the process of building and planning Dokk1 had to be a participatory and involving one. Through hundreds of workshops, meetings, interviews, focus groups, and prototyping we have successfully involved citizens, stakeholders, partners, politicians, etc. ${ }^{2} \mathrm{By}$ involving the people who was going to use Dokk1 it was possible to generate a lively urban space. Furthermore, it was important for the project to establish network and cooperation that involved institutions and local Aarhus ${ }^{3}$

planned and executed by partners and citizens. Learn more about Dokk1 at dokk1.dk/english/. Join our international Next Library Community at nextlibrary.net. In 2020 there will be a Next Library Satellite in Brisbane, and in 2021 it will be back in Aarhus.

2 Dalsgaard and Eriksson (2013).

3 The city of Aarhus has 330,000 inhabitants, 1 main library (Dokk1, www.dokk1.dk/english) and 18 branch libraries in various sizes. Net budget for the libraries is appr. $15 \mathrm{~m}$ Euro. 
companies in order to have them contribute with knowledge sharing, sparring, and inspiration.

In a process like this, citizens serve as inspiration and provide insight into what needs to be changed. In the light of this development, the libraries are heading towards a new innovation practice that focuses on co-creation with the users. This means including the users and activating the knowledge that they may not know they have and in this way enhance the users' sense of ownership and commitment in relation to the library. From being those for whom we design something, the users become, to a greater extent, a part of the process and we design with them and not just for them. The new innovation practice in Dokk1 has been on its way for years through many projects and programs, which have applied different processes to create changes in collaboration with the users. These participatory processes have made Dokk1 what it is today. An inclusive and open building that creates a new urban space that also reaches out and invites partners, citizens, and the community to play a central role in creating a lively and open space for all.

To find out how to involve the citizens and the community when designing library services we looked for inspiration in the field of participatory design and human-centered design. To create a shared language around innovation we chose to use design thinking as the overall mindset and approach at Aarhus Public Libraries. Design thinking gives you a set of tools and methods - but also a mindset. We use it to set the stage for the way we work and our approach to developing new services. ${ }^{4}$

\section{The design thinking toolkit}

Building and planning Dokk1 has been a huge user-involvement process but all over the world libraries ask: What's the future of libraries and how do we stay relevant as institution for our community? Aarhus Public Libraries and Chicago Public Library wanted to answer this question and help libraries find out how to use design methods to get to know the needs of their community. With support from Bill and Melinda Gates Foundation we engaged IDEO (an international design company) and did a project about design thinking and how it might best be adapted and applied to a library context. The final result was released

4 Thanks to partners, network and citizens for taking part in the process of creating Dokk1 and for keep using it as an ongoing lab for experimentations and participation. in 2015 as the Design Thinking Toolkit for Libraries. ${ }^{5}$ The toolkit can be used by any front-line library staffer to adapt to library users' changing needs. The idea is to help library staff all over the world to become the best possible changeagents that they can, in order to help their patrons and their communities learn and grow.

The toolkit guides you through Design Thinking so you can start coming up with solutions to everyday challenges within the library. Design thinking, or human-centered design, is all about starting with people-the users that visit your library.

\section{What is design thinking?}

Design thinking is an iterative process, which is user-centric and based on a deep understanding of the users' needs combined with experiments and prototypes. It is about getting out and away from the desk and the meeting room seeing the world in a fresh perspective. This will enable us to learn something new about the library and the users that we know so well.

The design thinking process consists of three phases:

1. Inspiration: Learn something about the world.

2. Ideation: Analyze what you have learnt and get ideas.

3. Iteration: Build prototypes and learn more about your users.

These three phases are repeated over and over in an iterative process.

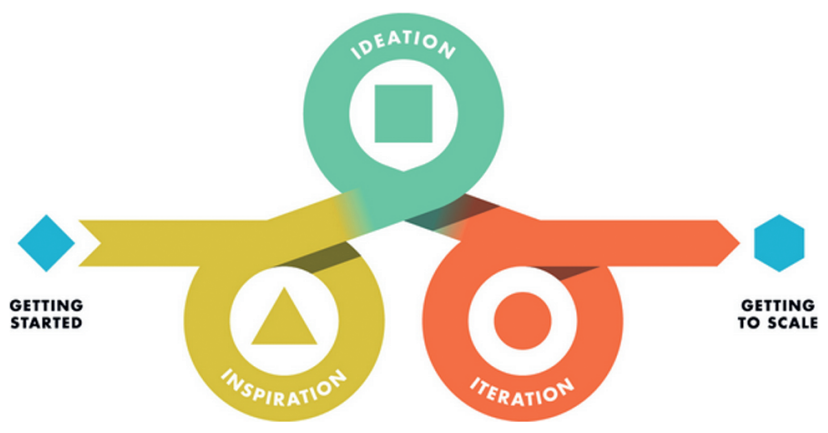

Fig. 2: The design thinking process consists of three phases. Illustration from the toolkit: "Design Thinking for Libraries"

Applying design thinking and service design, we can ensure that we base interior design, technology, and new

5 IDEO (2015). On the website you will also find a quick guide, methods, and cases to inspire you to get started using design thinking, www.designthinkingforlibraries.com. 
services on knowledge rather than assumptions about the users. In other words, it is not a question of asking the users, it is about observing them and understanding how they feel and experience a service or a visit to the library.

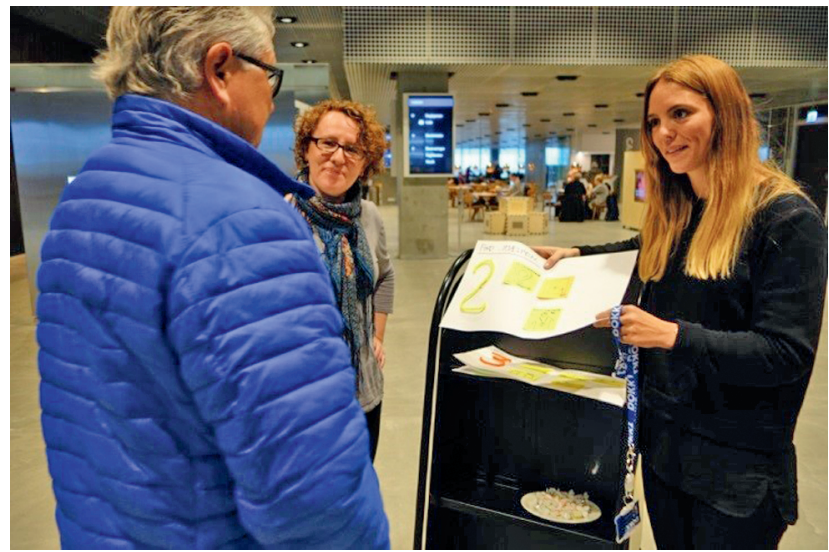

Fig. 3: In a design thinking process, ideas are prototyped at an early stage. Different concepts are presented to users at the checkout desk to obtain feedback. Photo: Aarhus Public Libraries

\section{But what if the citizens don't know what they want?}

It is crucial to understand that design thinking and cocreation is not asking what specific requirements citizens have to libraries, but instead it is about getting new inspiration and revealing needs through interviews, observations, visualization, and testing of prototypes. When you ask the citizens what kind of library services they need they often don't know it. But by using design research we can gain insights that can show us what we should design.

If you want to create a library in collaboration with the users, you need to embrace co-creation and design thinking as a new mindset and as toolbox of methods. Part of the process and the problem-solving is to identify the right problem. In order to do this, you need to open up the organization and invite the citizens to participate in the development. You have to do a lot of prototyping before you end up on a design that works. But in the process you will also learn a lot about the users: Whether an experiment or a prototype is successful or fails is far less important than the learning we gain from experimenting in collaboration with the users.

Co-creation processes are not driven by a focus on the organization's needs or an idea that an employee has come up with, but rather by a focus on and an understanding of the users' situations and needs. When you have this understanding you can figure out what problems you should solve. A number of methods can serve to obtain insights for this. Anything from a chat with users about what they like about a service and, and very important: what they do not like, to longer interviews and observations of user can be used to gain these insights.

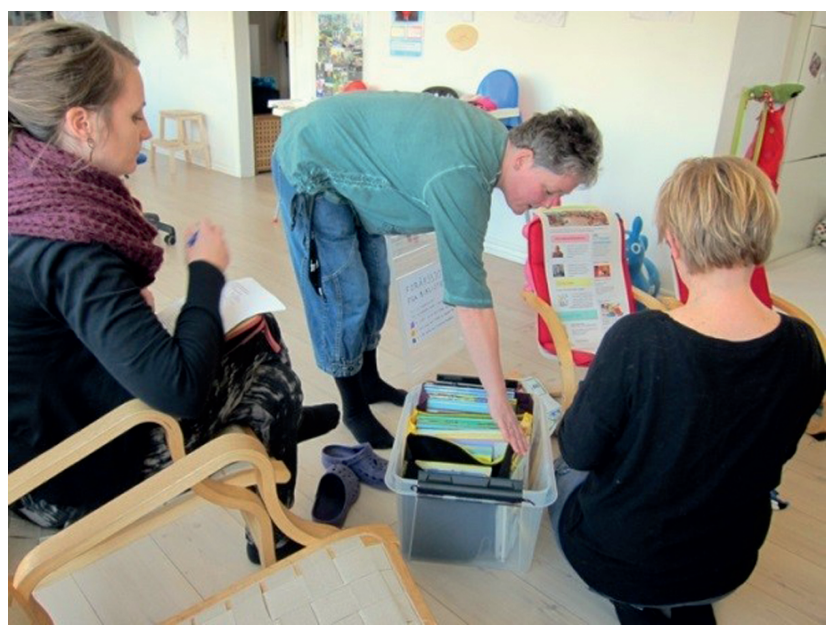

Fig. 4: A design team is processing the inputs they have gathered from the users. It is a question of digging a bit deeper and understanding what the real problem is. Photo: Aarhus Public Libraries

\section{Design thinking in use today}

Using design thinking has been a way for us to learn more about our users. Through interviews and prototyping we learned a lot of new things about our users and the way they use the library. We also learned that sometimes it is in the packaging and not in the service itself that a problem dwells. We learned new methods to focus not on demographics (gender, age, etc.) but more on behaviors as well. The user's habits, rituals, routines, and their journey through the library system often tell us more about who they are than for example their age.

Design thinking has brought the users to the center of our libraries and our development. It has given us tools to design together with our users and not just for them. When asked: how and where can we see how this approach has affected the library: the services, the interior, the shelves, etc. we often have to answer that this human-centered approach has affected almost every part of Dokk1: The area for users with reading difficulties is designed with a mix of easyto read books but also DIY books and books that address some of the hobbies this user group has. We learned this by interviewing non-readers and by prototyping with them.

In the area for children and families you will find lots of elements and spaces that allow families to do things 
together: e.g. read, play and create things. Also something we learned through the process. Another important learning from design thinking is that this way of working can help you build relations and grow your community. Partnerships have become extremely important for us to make sure that the library stays vibrant and relevant; right now we have at least 130 active partnerships. When we are approaching new projects and user groups we think carefully about: which partners can help us here and which partners, organizations, etc. can help us get more insights about the particular users?

\section{The library as an ongoing prototype}

Design thinking has become part of the DNA of our library culture-and it is the method we use when we approach new projects and services or if we need to solve a problem. It has played a central role in developing Dokk1 but also our branch libraries. We see all our libraries in Aarhus as ongoing prototypes where we test things, try our new concepts, change the space, etc. We try to spend less time talking about problems or ideas, instead we focus on testing them out and to think and act at the same time.

The library can be seen as an ongoing prototype but not only for us as library staffers, but also for the city and the citizen. We like to think of the library space as an innovation space for the community. This is also part of our strategy: to also think about design thinking and the mindset behind design thinking as part of our library service. Once the library was seen as a repository of knowledge but in the $21^{\text {st }}$ century it should also be a space where new ideas are born and new knowledge is created. There should be a space where citizens can engage in playful and hands-on experiments, where the citizens can use the design thinking approach to solve their problems.

In The four spaces - A new model for the public library Jochumsen et al. argue for the need to redefine Danish libraries as spaces for innovation, defined as "finding new answers to practical problems or developing completely new concepts, methods, or artistic expressions."

With this in mind we see a need to explore and develop performative spaces that support the users' creativity and innovation. We see this vision as crucial for the future of public libraries and an opportunity to rebrand libraries from 'warehouses for books' to 'centers of creativity and social innovation.' If the growth of welfare is to continue, innovation from citizens and communities is demanded. New skills among citizens are required, for example critical thinking, problem solving, creativity, innovation, communication, and collaboration. Therefore, we provide design thinking as a service the citizens can sign up for - in that way it also becomes a method they can use to develop and realize their ideas and visions.

\section{The library as a space for transformation}

The library should be the local innovation hub for the community. To support the library as an innovation space we established the Transformation Lab more than 10 years ago. The Transformation Lab is a space for prototyping and creating new images of the physical library of the future. Before Dokk1 opened experiments was carried out publicly in the foyer of the old Main Library in Aarhus. Here ideas and tangible models were tested in close interaction with both employees and library users. One of the contributions of the Transformation Lab was that it rendered the users visible in the library.

Transformation Lab showed us that users want to engage in making the library of the future. An advice for all libraries is to make room for an open space in the library that is never fully designed and thus may be changed on short notice. Here, it is possible to experiment with the dissemination of specific subjects as well as the physical settings, which may be continuously adjusted according to user inputs. This change the patrons' imagination of what a library can be and the library is no longer just the librarians' space but the users' space.

\section{Conclusion}

The library of the future should be co-created with the citizens. We have to prototype and co-create with users and we have to listen to users input and acknowledge them as a resource. In order to do this, we have to incorporate new roles and work in new ways in libraries, for example by using design thinking. With spaces for transformation we can move the physical library space in new directions. We also have to think of the library as an ongoing prototype that will change according to the needs of the community

Aarhus and Chicago Public Libraries still work together to find out how to spread these methods to the library field. Since launching in January 2015, the toolkit has been downloaded by over 20,000 librarians in more than 100 countries and has been translated into 15 lan- 
guages, e.g. German, Romanian, Japanese, and Spanish, with more planned in the future.

This article will therefore end up with an invitation to library people in Germany to join this global movement of library design thinkers. If you have stories and cases to share don't hesitate to reach out to us.

\section{References}

Dalsgaard, P.; Eriksson, E. (2013): Large-scale Participation: A Case Study of a Participatory Approach to Developing a New Public Library. Proceedings of the SIGCHI Conference on Human Factors in Computing Systems. New York, 399-408.

IDEO, Chicago Public Libraries and Aarhus Public Libraries (2015): Design Thinking for Libraries- A toolkit for patron-centereddesign. Available at www.designthinkingforlibraries.com.

Hapel, R.; Schulz, K.; Østergård, M.; Jensen, K.H. (ed.) (2015): Rum til forandring. Space for Change. Dokk1-Aarhus' nye mødested. Aarhus' New Meeting Space. Aarhus Kommunes Biblioteker, Aarhus, Denmark. Jochumsen, Henrik; Rasmussen, Casper Hvenegaard; Skot-Hansen. Dorte (2012): The four spaces - A new model for the public library. In: New Library world, 113 (11/12).

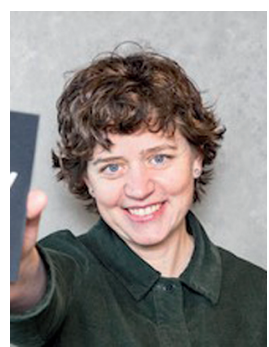

\section{Sidsel Bech-Petersen}

Hack Kampmanns Plads 2

DK-8000 Aarhus C

sibp@aarhus.dk

Photo: Aarhus Public Libraries 